J. Amer. Soc. HorT. SCI. 15(3):412-416. 1990.

\title{
Influence of Frequency and Dates of Plant Growth Regulator Applications to Centipedegrass on Seedhead Formation and Turf Quality
}

\author{
Billy J. Johnson ${ }^{1}$ \\ Department of Agronomy, University of Georgia, Georgia Station, Griffin, GA 30223-1797 \\ Additional index words. Eremochloa ophiuroides, turf injury, seedhead suppression, growth retardation
}

\begin{abstract}
Two separate experiments (one and two applications and dates of treatment) were conducted on plant growth regulator (PGR) injury and seedhead suppression of centipedegrass [Eremochloa ophiuroides (Munro) Hack.]. Mefluidide caused less injury to centipedegrass than either imazethapyr or flurprimidol + mefluidide. Mefluidide applied at $0.56 \mathrm{~kg}^{-1} \mathrm{ha}^{-1}$ in each of two applications at 2-week intervals suppressed seedheads of centipedegrass for 10 weeks. A single $0.56-\mathrm{kg}^{-1} \mathrm{ha}^{-1}$ application of the mefluidide failed to suppress seedheads when applied any time from mid-June until late July. A single treatment with flurprimidol + mefluidide severely injured centipedegrass, and seedhead suppression was poor regardless of date of treatment. Centipedegrass was severely injured when flurprimidol + mefluidide was applied at $1.68+0.28 \mathrm{~kg}^{\circ} \mathrm{ha}^{-1}$ in each of two applications, but seedheads were suppressed for 10 weeks. Imazethapyr applied at 0.30 and followed by $0.15 \mathrm{~kg} \cdot \mathrm{ha}^{-1}$ suppressed seedheads 10 weeks after treatment in 1987 and 6 weeks after treatment in 1988 without reducing turf density. When this PGR was applied as a single treatment at $0.30 \mathrm{~kg} \cdot \mathrm{ha}^{-1}$, seedhead suppression was generally greater for 8 weeks when applied mid- to late July than mid- to late June. Chemical names used: $\mathbf{N}-[2,4-d i m e t h y l-5-[[($ trifluoromethyl)sulfonyl $]$ amino $]$ phenyl $]$ acetamide (mefluidide); $\alpha$-(1-methylethyl)- $\alpha$-[4-(trifluoromethoxy)phenyl]-5-pyrimidinemethanol (flurprimidol); and ( \pm )-2-[4,5dihydro-4-methyl-4-(1-methylethyl)-5-oxo-1H-imidazol-2-yl]-5-ethyl-3-pyridinecarboxlic acid (imazethapyr).
\end{abstract}

Plant growth regulators are applied to turfgrasses to retard vegetative growth and/or to suppress seedheads. Centipedegrass is a low-maintenance grass (Johnson et al., 1988a, 1988b) and requires only infrequent mowing throughout the growing season; therefore, PGRs are generally not needed for the suppression of vegetative growth of this species. However, centipedegrass seedheads are numerous during mid-summer, and frequent mowing is required to maintain a turf free of seedheads. If PGRs could be applied to centipedegrass to inhibit seedhead formation, mowing frequency could be reduced during this period.

Plant growth regulators have been evaluated for seedhead suppression of cool-season grasses (Bhowmik, 1987; Christians, 1985; Demoedon, 1984; Johnson, 1989b; McCarty et al., 1985). However, limited information is available on centipedegrass, for which a single treatment with either imazethapyr, mefluidide, or flurprimidol + mefluidide did not effectively suppress seedhead development for 8 weeks (Johnson, 1989a). In that experiment, imazethapyr suppressed $>70 \%$ of centipedegrass seedheads for 6 weeks, but severely injured the grass in 1 of 2 years. Neither mefluidide applied alone nor with flurprimidol effectively suppressed seedheads during this period.

Kaufmann (1985) reported that the preferred time to apply a PGR to cool-season grasses is just before the peak growth period. Seedhead suppression of tall fescue (Festuca arundinacea Schreb. 'Ky 31') in North Carolina (DiPaola et al., 1985) was unacceptable when PGRs were applied later than 2 weeks before the emergence of the inflorescences. Plant growth regulators applied in late May to common bermudagrass [Cynodon dactylon (L.) Pers.] in Arkansas (Rogers et al., 1987) suppressed vegetative growth more than when applied in July. Similar re-

\footnotetext{
Received for publication 6 Feb. 1989. Supported by state and Hatch Act funds allocated to the Georgia Agricultural Experiment Stations. I thank Jerry Davis, station statistician. for his cooperation in these studies and gratefully acknowledge R. Waites and T. Dinkins for technical assistance. The cost of publishing this paper was defrayed in part by the payment of page charges. Under postal regulations, this paper therefore must be hereby marked advertisement solely to indicate this fact.

${ }^{1}$ Professor.
}

suits were also observed on 'Tifway' bermudagrass (C. transvaalensis Burtt-Davy) $\times$ [C. dactylon (L.) Pers.] in Georgia (Johnson, 1988).

To obtain a more consistent response of PGRs on centipedegrass, experiments were conducted to determine the effects of one and two PGR applications and dates of PGR treatments on injury and seedhead suppression of centipedegrass.

\section{Materials and Methods}

Two PGR experiments were conducted on a mature stand of centipedegrass maintained at a 4.5-cm cutting height during 1987 and 1988. In both experiments, the turf was cut with a rotary mower and clippings were returned up to 1 week before treatment. On the day of treatment, the grass was cut and clippings were removed. At 2-week intervals after PGR treatments, onehalf of each plot was mowed and one-half -was not mowed throughout the study. Centipedegrass is normally mowed at 2week intervals in Georgia.

One and two PGR applications (Expt. 1). Centipedegrass was treated with mefluidide, flurprimidol + mefluidide, and imazethapyr at various amounts in one or two applications (Table 1). An untreated control was included. Dates of treatments were 30 June and 15 July 1987 and 7 and 19 July 1988. Plant growth regulator treatments were arranged in a randomized completeblock design with four replications. Since one-half of the plots was mowed and one-half was not mowed, a split-block arrangement was created; treatments in the mowed and unmowed plots were analyzed separately.

Date of PGR application (Expt. 2). Centipedegrass was treated with a single application of mefluidide at $0.56 \mathrm{~kg} \cdot \mathrm{ha}^{-1}$, flurprimidol + mefluidide at $1.68+0.28 \mathrm{~kg} \cdot \mathrm{ha}^{-1}$, and imazethapyr at $0.30 \mathrm{~kg} \cdot \mathrm{ha}^{-1}$ on 16 June, 30 June, 15 and 27 July 1987; and on 16 June, 28 June, 13 July, and 26 July 1988. An untreated control was included at each date of treatment. The experimental design was a split plot with four replications in 1987 and three replications in 1988. Dates of PGR treatments were randomized within blocks for the whole plots and PGR treatments were randomized within subplots. 
Table 1. Influence of one and two plant growth regulator applications on injury of centipedegrass in Expt. 1 at Griffin, Ga.

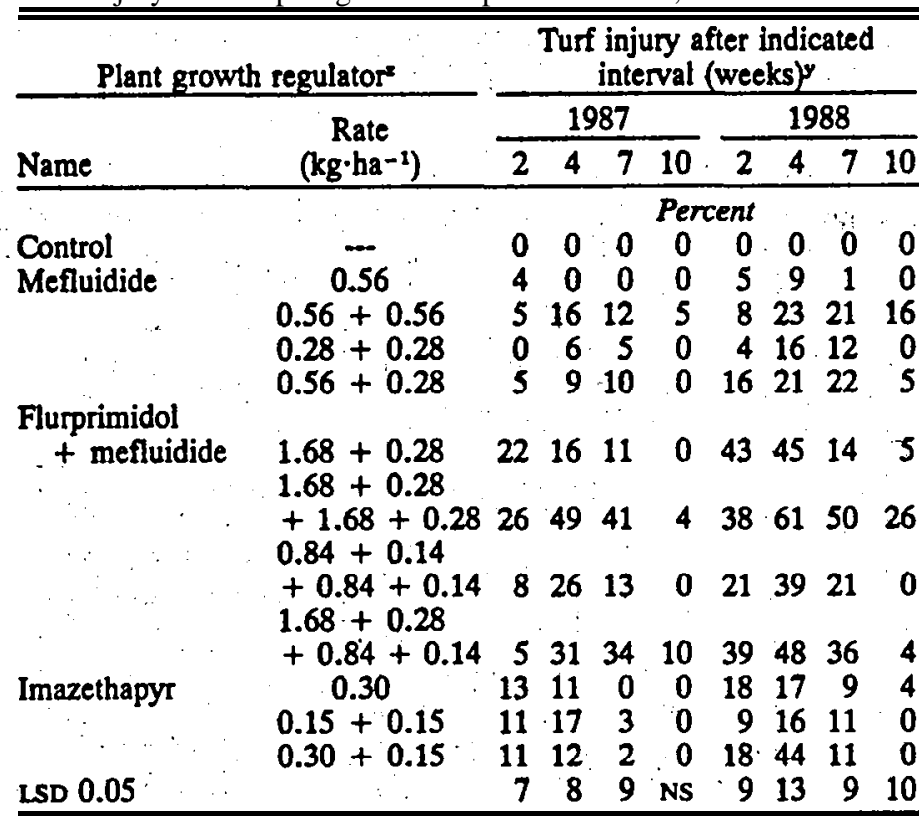

${ }^{\mathrm{z}}$ Treatments were applied 30 June and 15 July 1987 and 7 and 19 July 1988. When PGRs were applied only once, it was at the earliest date. ${ }^{\mathrm{y}}$ Turfgrass injury was rated at times indicated after the first PGR treatment and baaed on $0=$ no injury, $\geq 30=$ unacceptable, and $100=$ complete kill. Data are the means of four observations.

Nonsignificant.

General information. A nonionic surfactant (alkylarylpolyoxyethylene glycols free fatty acid isopropanol) was applied with mefluidide and flurprimidol + mefluidide at $0.5 \%(\mathrm{v} / \mathrm{v})$ and with imazethapyr at $0.25 \%(\mathrm{v} / \mathrm{v})$. Treatments were applied to different plots each year. Plot size was $1.5 \times 3 \mathrm{~m}$. The PGRs were applied as a broadcast spray in 375 liter of water/ha.

The soil type in both experiments was a Cecil sandy loam (clayey Kaolinitic Thermic Typic Hapludult) with $1.3 \%$ organic matter, $72 \%$ sand, $18 \%$ silt, and $10 \%$ clay in 1987 and with $2.2 \%$ organic matter, $64 \%$ sand, $19 \%$ silt, and $17 \%$ clay in 1988. The turfgass was fertilized each year with (all in $\mathrm{kg} \cdot \mathrm{ha}^{-1}$ ) $50 \mathrm{~N}, 22 \mathrm{P}$, and $42 \mathrm{~K}$ in early April. Centipedegrass was irrigated before and after treatment as needed to prevent wilting.

Injury, density, and seedhead suppression of centipedegrass were rated visually. The injury ratings were made in the mowed areas from 1 to 10 weeks after PGR applications and based on $0=$ no injury and $100=$ complete kill. Injury $\geq 30 \%$ was considered to be severe and would not be commercially acceptable. Turf density ratings, made 6 to 10 weeks after PGR treatments, were based on $1=$ no grass and $10=$ complete uniform cover, and they were transformed to percent of untreated check. Seedhead suppression ratings were made in unmowed areas from 3 to 10 weeks after PGR applications and based on $100=$ no seedheads and $0=$ uniform seedhead cover. Seedhead suppression of $\geq 70 \%$ would be commercially acceptable. Vegetative height measurements were made from five plants per replicated plot. The measurements were made from soil surface to tip of new leaves. The height was taken in mowed areas before each biweekly mowing and in unmowed areas at the end of 10 weeks.

Analysis of variance using the statistical analysis system, general linear model procedure, (SAS, 1982) was performed within
1987 and 1988 and across years in Expts. 1 and 2. There were year $\times$ treatment interactions for the injury, density, and seedhead suppression in each experiment, and data are reported for each year. There was no year $\times$ treatment interaction for mean vegetative height in each experiment, and data are reported as averages for years. Treatment means were separated by LSD at $P=0.05$

\section{Results and Discussion}

\section{One and two PGR applications (Expt. 1)}

Turf injury. Mefluidide applied as a single treatment at 0.56 $\mathrm{kg} \cdot \mathrm{ha}^{-1}$ injured centipedegrass only slightly (Table 1 ). In most instances, the injury was similar whether $0.56 \mathrm{~kg} \cdot \mathrm{ha}^{-1}$ was applied as a single application or $0.28 \mathrm{~kg} \cdot \mathrm{ha}^{-1}$ was applied in each of two applications. Mefluidide applied at $0.56 \mathrm{~kg} \cdot \mathrm{ha}^{-1}$ in each of two applications caused $16 \%$ centipedegrass injury in 1987 and $23 \%$ in 1988 at 4 weeks after the initial application. The injury in 1988 significantly reduced density of turf according to ratings made 10 weeks after the first mefluidide treatment (Table 2).

Flurprimidol + mefluidide at $1.68+0.28 \mathrm{~kg} \cdot \mathrm{ha}^{-1}$ as a single application injured centipedegrass too severely in 1 of 2 years to be acceptable (Table 1). The highest injury (45\%) was at 4 weeks after treatment in 1988. This was higher than obtained in $1987(22 \%)$ or in an earlier study (29\%) (Johnson, 1989a). There was no difference in 1988 whether flurprimidol + mefluidide was applied as a single treatment at $1.68+0.28$ $\mathrm{kg} \cdot \mathrm{ha}^{-1}$ or at the one-half rate in each of two applications at 4 weeks or later. When the full rate was applied twice, maximum

Table 2. Influence of one and two plant growth regulator applications on density of centipedegrass in Expt. 1 at Griffin, Ga.

\begin{tabular}{|c|c|c|c|}
\hline \multicolumn{2}{|c|}{ Plant growth regulator ${ }^{z}$} & \multirow{2}{*}{\multicolumn{2}{|c|}{$\begin{array}{c}\text { Turf density } \\
\text { (\%o of untreated) }\end{array}$}} \\
\hline \multirow[b]{2}{*}{ Name } & \multirow{2}{*}{$\begin{array}{c}\text { Rate } \\
\left(\mathrm{kg} \cdot h \mathrm{ha}^{-1}\right)\end{array}$} & & \\
\hline & & 1987 & 1988 \\
\hline Control & --- & 100 & 100 \\
\hline \multirow{4}{*}{ Mefluidide } & 0.56 & 102 & 100 \\
\hline & $0.56+0.56$ & 103 & $85^{*}$ \\
\hline & $0.28+0.28$ & 102 & 96 \\
\hline & $0.56+0.28$ & 101 & $88^{*}$ \\
\hline \multicolumn{4}{|l|}{ Flurprimidol } \\
\hline \multirow[t]{4}{*}{+ mefluidide } & $\begin{array}{l}1.68+0.28 \\
1.68+0.28\end{array}$ & 99 & 96 \\
\hline & $\begin{array}{l}+1.68+0.28 \\
0.84+0.14\end{array}$ & 104 & $84^{*}$ \\
\hline & $\begin{array}{l}+0.84+0.14 \\
1.68+0.28\end{array}$ & 104 & 97 \\
\hline & $+0.84+0.14$ & 97 & 99 \\
\hline \multirow[t]{3}{*}{ Imazethapyr } & 0.30 & 108 & 97 \\
\hline & $0.15+0.15$ & 108 & 100 \\
\hline & $0.30+0.15$ & 109 & 99 \\
\hline LSD 0.05 & & 10 & 6 \\
\hline
\end{tabular}

${ }^{\mathrm{z}}$ Treatments were applied 30 June and 15 July 1987 and 7 and 19 July 1988. When PGRs were applied only once, it was at the earliest date. ${ }^{\mathrm{y}}$ Turf density ratings were made 10 weeks after first PGR treatment and based on percent of nontreated check. Data are the means of four observations.

*Indicates that the density of treated centipedegrass was significantly lower than nontreated. 
injury was $49 \%$ in 1987 and 61\% in 1988, 4 weeks after the first treatment. By 10 weeks, turf treated with flurprimidol + mefluidide had recovered fully in 1987, white the turf treated with the same PGR combination in 1988 did not. Turf injury from this PGR combination was also reflected in lower density in 1988 (Table 2). Flurprimidol + mefluidide applied at any other level to centipedegrass in 1988, or at any level in 1987 did not reduce turf density 10 weeks after treatment.

Imazethapyr applied at $0.3 \mathrm{~kg} \cdot \mathrm{ha}^{-1}$ as a single application or $0.15 \mathrm{~kg} \cdot \mathrm{ha}^{-1}$ in each of two applications injured the turf only slightly after treatment either year (Table 1). However, the injury from the single $0.3-\mathrm{kg} \cdot \mathrm{ha}^{-1}$ treatment in the present study was less than that obtained in an earlier study (Johnson, 1989a). The safety of imazethapyr on centipedegrass may be questionable, since the grass was severely injured (44\%) for a short period in 1 of 2 years when treated initially with $0.3 \mathrm{~kg} \cdot \mathrm{ha}^{-1}$ and followed by $0.15 \mathrm{~kg} \cdot \mathrm{ha}^{-1} 12$ days later. However, the injury was temporary, as the turf recovered rapidly and the treatment did not affect density (Table 2).

Seedhead suppression. Mefluidide applied at $0.56 \mathrm{~kg} \cdot \mathrm{ha}^{-1}$ as a single treatment did not effectively suppress centipedegrass seedheads (Table 3 ). However, the suppression was $\approx 70 \%$ for 8 weeks when mefluidide was applied at 0.56 and followed with $0.28 \mathrm{~kg} \cdot \mathrm{ha}^{-1}$. When $0.56 \mathrm{~kg} \cdot \mathrm{ha}^{-1}$ was applied in two applications, the suppression was between $70 \%$ and $80 \%$ for 10 weeks.

Flurprimidol + mefluidide did not suppress seedheads of centipedegrass equally each year. Seedheads were effectively suppressed with a single application of flurprimidol + mefluidide at $1.68+0.28 \mathrm{~kg} \cdot \mathrm{ha}^{-1}$ for 8 weeks in 1987 , but only for 4 weeks in 1988 (Table 3). There was no significant benefit in length of suppression from flurprimidol + mefluidide when treated twice at the full + one-half amounts compared with a single full amount. However, the suppression at 10 weeks was

Table 3. Influence of one and two plant growth regulator applications on seedhead suppression of centipedegrass in Expt. 1 at Griffin, Ga.

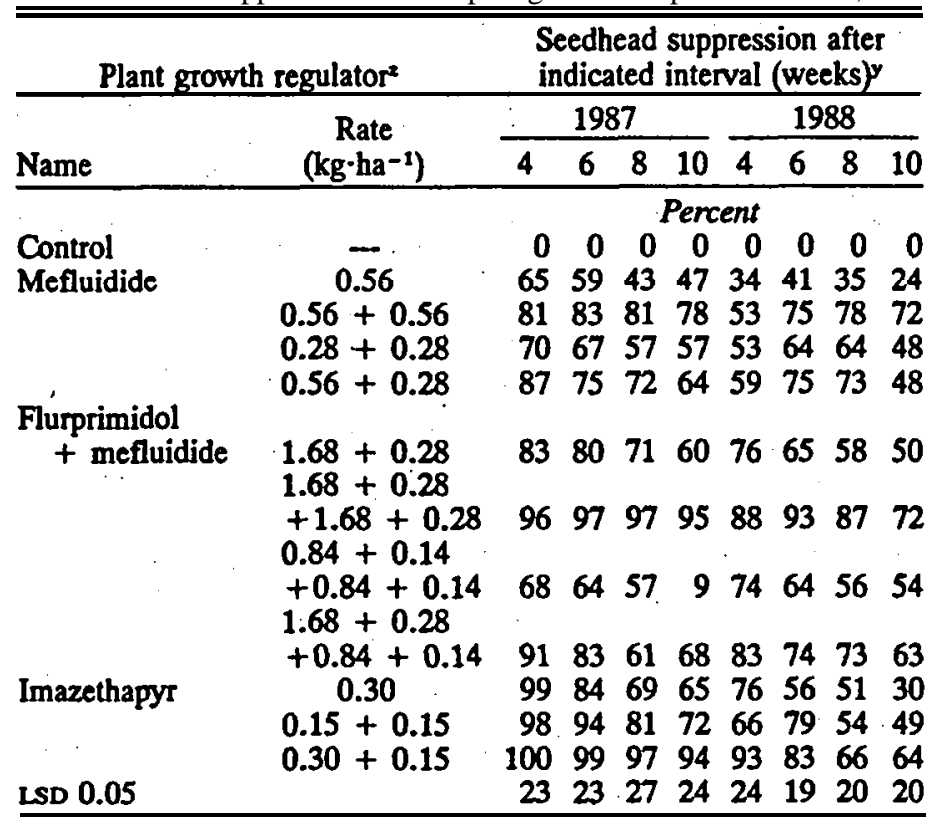

Treatments were applied 30 June and 19 July 1987 and 7 and 19 July 1988. When PGRs were applied only once, it was at the earliest date. ${ }^{\mathrm{y}}$ Seedhead suppression was rated at times indicated after the first PGR treatment and based on $0=$ no suppression, $\geq 70 \%=$ acceptable, and $100=$ complete suppression with no seedheads. Data are the means of four observations.
95\% in 1987 and $72 \%$ in 1988 when the grass was treated twice at the full amount.

Imazethapyr suppressed seedheads of centipedegrass more in 1987 than 1988 (Table 3). A single $0.30-\mathrm{kg} \cdot \mathrm{ha}^{-1}$ treatment sup pressed seedheads for 6 weeks in 1987, but only for 4 weeks in 1988. In an earlier study (Johnson, 1989a), suppression persisted for 6 weeks. Although not significant, the suppression with imazethapyr was improved in the present study in 1987 when applied at $0.15 \mathrm{~kg} \cdot \mathrm{ha}^{-1}$ in each of two applications compared with a single $0.30-\mathrm{kg} \cdot \mathrm{ha}^{-1}$ treatment. When the PGR was applied at $0.30 \mathrm{~kg} \cdot \mathrm{ha}^{-1}$ and followed with $0.15 \mathrm{~kg} \cdot \mathrm{ha}^{-1}$, the suppression was improved to $94 \%$ at 10 weeks in 1987 and $83 \%$ at 6 weeks in 1988. The suppression in 1988 was reduced to $66 \%$ by 8 weeks.

Vegetative height. Centipedegrass maintained under low fertility level grew slowly, and the grass generally did not respond to PGRs except when not mowed. The grass not mowed was suppressed for 8 weeks when treated with a single application of mefluidide at $0.56 \mathrm{~kg} \cdot \mathrm{ha}^{-1}$ (Table 4). Growth suppression was increased to 10 weeks when $0.28 \mathrm{~kg} \cdot \mathrm{ha}^{-1}$ was applied in each of two applications.

Flurprimidol + mefluidide suppressed the vegetative growth of nonmowed centipedegrass for 10 weeks (Table 4). The growth at 10 weeks was suppressed $28 \%$ in plots treated once with flurprimidol + mefluidide at $1.68+0.28 \mathrm{~kg} \cdot \mathrm{ha}^{-1}$ but suppressed nearly twice as much when treated with $1.68+0.28$ $\mathrm{kg} \cdot \mathrm{ha}^{-1}$ in each of two applications.

Imazethapyr suppressed vegetative growth of nonmowed centipedegrass, but amount and sequence of applications influenced the length of suppression (Table 4). When the PGR was applied at $0.3 \mathrm{~kg} \cdot \mathrm{ha}^{-1}$ as a single application, centipedegrass growth

Table 4. Influence of one and two plant growth regulator applications on vegetative height of nonmowed centipedegrass in Expt. 1 at Griffin, Ga.

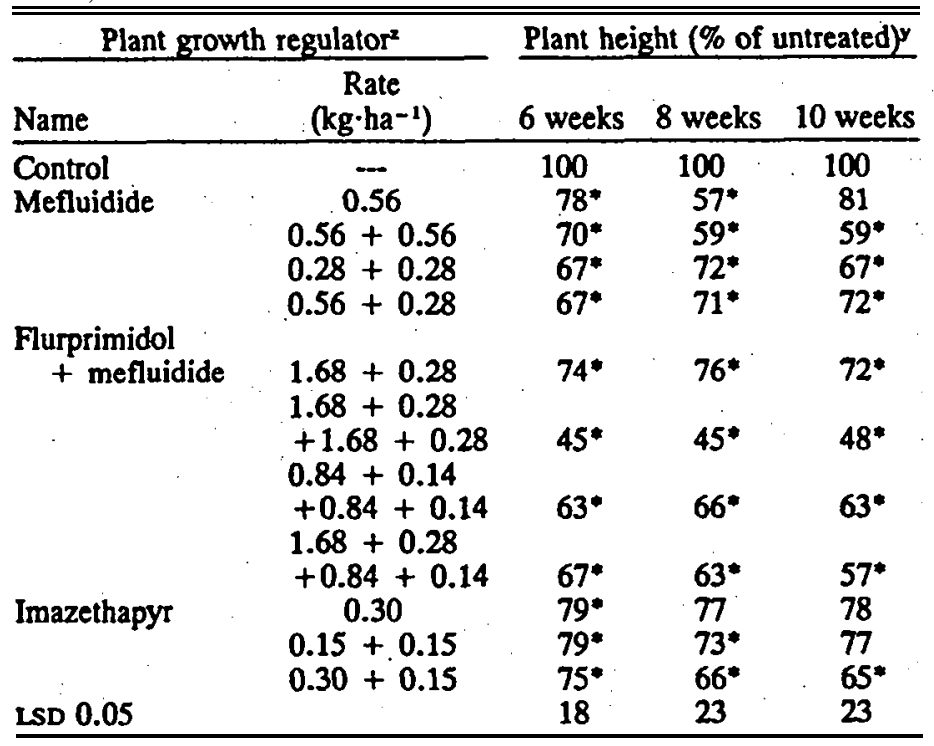

${ }^{\mathrm{z}}$ The first PGR treatment was applied 7 July and the second on 19 July. When PGRs were applied only once, it was at the earliest date.

${ }^{\mathrm{y}}$ Plant heights are averages from two years and ratings were made weeks after the first treatment and based on percent of nontreated check. The height of nontreated grass was $9.7 \mathrm{~cm}$ at 6 weeks, 14.3 $\mathrm{cm}$ at 8 weeks, and $15.5 \mathrm{~cm}$ at 10 weeks. Data are the means of four observations.

*Indicates that the height of treated centipedegrass was significantly lower than nontreated. 
was suppressed for 6 weeks, but was suppressed for 8 weeks when applied at $0.15 \mathrm{~kg} \cdot \mathrm{ha}^{-1}$ in each of two applications. The suppression was increased to 10 weeks when treated with imazethapyr at $0.3 \mathrm{~kg} \cdot \mathrm{ha}^{-1}$ and followed by $0.15 \mathrm{~kg} \cdot \mathrm{ha}^{-1}$.

The commercial use of PGRs on centipedegrass depends on injury to the grass and length of seedhead suppression. From the PGRs evaluated in this study, mefluidide applied at 0.56 $\mathrm{kg} \cdot \mathrm{ha}^{-1}$ in each of two applications provided suppression with minimum turf injury during a 10 -week period. A combination of flurprimidol + mefluidide severely injured centipedegrass in 1 of 2 years when applied as a single application, and seedhead suppression was not as good as with two mefluidide treatments at $0.56 \mathrm{~kg} \cdot \mathrm{ha}^{-1}$. Imazethapyr applied in two applications $(0.30$ $\mathrm{kg} \cdot \mathrm{ha}^{-1}$ in the first and $0.15 \mathrm{~kg} \cdot \mathrm{ha}^{-1}$ in the second) suppressed seedheads of centipedegrass from 6 to 10 weeks, but severely injured the turf in 1 of 2 years..

\section{Date of PGR treatments (Expt. 2)}

The amount of injury and seedhead suppression of centipedegrass in the multiple-treatment experiment was influenced by the PGRs, but all treatments caused some degree of plant injury. Therefore, when PGRs are used, it is desirable to select dates of treatment where the least injury and highest seedhead suppression occur.

Turf injury. Mefluidide did not severely injure ( $\leq 30 \%$ ) centipedegrass at any of the treatment dates (Table 5). However, less injury was noted when the PGR was applied 29 June (12\% to $17 \%$ ) or 14 July (15\% to $18 \%$ ) than when applied 16 June ( $23 \%$ to $25 \%$ ) or 27 July ( $18 \%$ to $28 \%$ ) when rated 3 weeks after treatment. However, with the variation, there was no clear

Table 5. Influence of date of plant growth regulator application on injury of centipedegrass at Griffin, Ga.

\begin{tabular}{|c|c|c|c|c|c|c|c|}
\hline \multirow{3}{*}{\multicolumn{2}{|c|}{ dates }} & \multicolumn{6}{|c|}{ Turfgrass injury $(\%)^{y}$} \\
\hline & & \multicolumn{4}{|c|}{$\begin{array}{c}\text { Flurprimidol } \\
+ \\
\text { mefluidide } \\
\end{array}$} & \multicolumn{2}{|c|}{ Imazethapyr } \\
\hline & & 1987 & 1988 & 1987 & 1988 & 1987 & 1988 \\
\hline & & \multicolumn{6}{|c|}{3 weeks } \\
\hline $\begin{array}{l}16 \text { June } \\
29 \text { June } \\
14 \text { July } \\
27 \text { July } \\
\text { LSD } 0.05\end{array}$ & ' & $\begin{array}{l}10 \\
12 \\
15 \\
28 \\
10\end{array}$ & $\begin{array}{l}25 \\
17 \\
18 \\
18 \\
\text { NS }\end{array}$ & $\begin{array}{r}34 \\
43 \\
35 \\
36 \\
5\end{array}$ & $\begin{array}{l}38 \\
47 \\
36 \\
43 \\
\text { NS }\end{array}$ & $\begin{array}{r}22 \\
39 \\
23 \\
29 \\
6\end{array}$ & $\begin{array}{l}27 \\
23 \\
29 \\
22 \\
\text { NS }\end{array}$ \\
\hline LSD 0.05 & & \multicolumn{6}{|c|}{ 6. weeks } \\
\hline $\begin{array}{l}16 \text { June } \\
29 \text { June } \\
14 \text { July } \\
27 \text { July } \\
\text { LsD } 0.05\end{array}$ & . & $\begin{array}{l}16 \\
22 \\
19 \\
21 \\
\text { NS }\end{array}$ & $\begin{array}{l}13 \\
17 \\
18 \\
20 \\
\text { NS }\end{array}$ & $\begin{array}{r}23 \\
36 \\
30 \\
28 \\
9\end{array}$ & $\begin{array}{r}35 \\
38 \\
21 \\
35 \\
9\end{array}$ & $\begin{array}{l}14 \\
23 \\
21 \\
21 \\
\text { NS }\end{array}$ & $\begin{array}{l}13 \\
17 \\
22 \\
33 \\
13\end{array}$ \\
\hline & & \multicolumn{6}{|c|}{10 weeks. } \\
\hline $\begin{array}{l}16 \text { June } \\
29 \text { June } \\
14 \text { July } \\
27 \text { July } \\
\text { LsD } 0.05\end{array}$ & & $\begin{array}{r}0 \\
13 \\
8 \\
3 \\
\text { NS }\end{array}$ & $\begin{array}{r}3 \\
5 \\
22 \\
10 \\
\text { NS }\end{array}$ & $\begin{array}{r}8 \\
20 \\
13 \\
6 \\
6\end{array}$ & $\begin{array}{r}5 \\
20 \\
7 \\
10 \\
6\end{array}$ & $\begin{array}{r}0 \\
8 \\
4 \\
6 \\
\text { NS }\end{array}$ & $\begin{array}{r}0 \\
0 \\
13 \\
15 \\
3\end{array}$ \\
\hline \multicolumn{8}{|c|}{$\begin{array}{l}{ }^{\mathrm{z}} \text { Mefluidide at } 0.56 \mathrm{~kg} \cdot \mathrm{ha}^{-1} \text {, flurprimidol }+ \text { mefluidide at } 1.68+ \\
0.28 \mathrm{~kg} \cdot \mathrm{ha}^{-1} \text {. and imazethapyr at } 0.30 \mathrm{~kg} \cdot \mathrm{ha}^{-1} \text { were applied } \pm 1 \text { day } \\
\text { at the different treatment dates in } 1987 \text { and } 1988 . \\
\text { y } \text { Turf grass injury ratings were based on } 0=\text { no injury, } \geq 30=\text { un- } \\
\text { acceptable, and } 100=\text { complete kill. Data are the means of four } \\
\text { observations.. } \\
\text { NS Nonsignificant. }\end{array}$} \\
\hline
\end{tabular}

date for the best mefluidide treatment. In most instances, mefluidide induced some degree of injury throughout the 10 weeks, but did not reduce turf density (data not shown).

The injury to centipedegrass was severe when treated with flurprimidol + mefluidide at any date when ratings were made 3 weeks after treatment (Table 5). Centipedegrass recovered more slowly when treated 29 June with the PGRs than at other dates when rated at 10 weeks.

Injury to centipedegrass treated with imazethapyr varied with dates of treatment (Table 5). Only with imazethapyr applied 29 June 1987 or 27 July 1988 was the injury $>30 \%$ throughout the 10 -week period. Although the difference in turf injury due to treatment dates may not always be significant, the injury from mefluidide was less when treated from 16 June until 14 July than when treated 27 July, and with imazethapyr when treated 16 June than at later dates. The injury of turf treated with flurprimidol + mefluidide was too severe to be applied to centipedegrass.

Seedhead suppression. When single PGR treatments were applied, the suppression of centipedegrass seedheads was more consistent with imazethapyr than with mefluidide or flurprimidol + mefluidide (Table 6). Imazethapyr suppressed seedheads of centipedegrass effectively for 4 weeks regardless of treatment date. However, by 6 weeks, the suppression was considered commercially acceptable only when the PGR was applied 14 or 27 July. At these dates, the effectiveness of imazethapyr did not last longer than 6 weeks in 1987, but persisted for 8 weeks in 1988. Seedhead suppression with mefluidide or flurprimidol + mefluidide was erratic in both years. By 8 weeks, the suppression of seedheads was effective with mefluidide when

Table 6. Influence of dates of plant growth regulator application on seedhead suppression of centipedegrass at Griffin, $\mathrm{Ga}$.

\begin{tabular}{|c|c|c|c|c|c|c|}
\hline \multirow[b]{3}{*}{ Treatment dates ${ }^{2}$} & \multicolumn{6}{|c|}{ Seedhead suppression $(G)^{y}$} \\
\hline & \multicolumn{2}{|c|}{ Mefluidide } & \multicolumn{2}{|c|}{$\begin{array}{c}\begin{array}{c}\text { Flurprimidol } \\
+ \\
\text { mefluidide } \\
\end{array} \\
\end{array}$} & \multicolumn{2}{|c|}{ Imazethapyr } \\
\hline & 1987 & 1988 & 1987 & 1988 & 1987 & 1988 \\
\hline & \multicolumn{6}{|c|}{4 weeks } \\
\hline 16 June & 68 & 99 & 38 & 99 & 88 & 99 \\
\hline 29 June & 73 & 50 & 63 & 72 & 98 & 90 \\
\hline 14 July & 69 & 83 & 51 & 66 & 90 & 99 \\
\hline 27 July & 65 & 78 & 63 & 68 & 86 & 98 \\
\hline \multirow[t]{2}{*}{ LSD 0.05} & NS & 17 & 18 & 11 & NS & NS \\
\hline & \multicolumn{6}{|c|}{6 weeks } \\
\hline 16 June & 50 & 73 & 50 & 72 & 53 & 82 \\
\hline 29 June & 45 & 53 & 43 & 68 & 65 & 65 \\
\hline 14 July & 45 & 85 & 36 & 63 & 74 & 91 \\
\hline 27 July & 63 & 68 & 70 & 45 & 79 & 79 \\
\hline \multirow[t]{2}{*}{ LSD 0.05} & NS & 19 & 16 & 13 & 18 & NS \\
\hline & \multicolumn{6}{|c|}{8 weeks } \\
\hline 16 June & 50 & 74 & 53 & 64 & 52 & 63 \\
\hline 29 June & 38 & 58 & 28 & 65 & 55 & 61 \\
\hline 14 July & 48 & 80 & 41 & 55 & 68 & 75 \\
\hline 27 July & 33 & 65 & 44 & 42 & 53 & 70 \\
\hline LSD 0.05 & NS & NS & 15 & 9 & NS & NS \\
\hline
\end{tabular}

${ }^{\mathrm{z}}$ Mefluidide at $0.56 \mathrm{~kg} \cdot \mathrm{ha}^{-1}$, flurprimidol + mefluidide at $1.68+$ $0.28 \mathrm{~kg} \cdot \mathrm{ha}^{-1}$, and imazethapyr at $0.30 \mathrm{~kg} \cdot \mathrm{ha}^{-1}$ were applied \pm 1 day at the different treatment dates in 1987 and 1988.

${ }^{\mathrm{y}}$ Seedhead suppression ratings were based on $0=$ no suppression, $\geq 70$ $=$ acceptable, and $100=$ complete suppression with no seedheads. Data are the means of four observations.

${ }^{\mathrm{NS}}$ Nonsignificant. 
applied 16 June or 14 July 1988, while flurprimidol + mefluidide was not effective at any date.

In summary, it was necessary to repeat mefluidide or flurprimidol + mefluidide treatments at 2 -week intervals, as shown in Expt. 1, to obtain effective seedhead suppression of centipedegrass throughout the summer without serious injury. Imazethapyr did not effectively suppress seedheads with two applications.

\section{Literature Cited}

Bhowmik, P.C. 1987. Response of a red fescue-Kentucky bluegrass turf to three consecutive annual applications of amidochlor, mefluidide, and ethephon. Weed Sci. 35:95-98.

Christians, N.E. 1985. Response of Kentucky bluegrass to four growth retardants. J. Amer. Soc. Hort. Sci. 110:765-769.

Demoedon, P.H. 1984. Four-year response of a Kentucky bluegrassred fescue turf to plant growth retardants. Agron. J. 76:807-813.

DiPaola, J.M., W.B. Gilbert, and W.M. Lewis. 1985. Turfgrass response to growth retardants. Fact Sheet Fla. Turf Dig. 2(1).

Johnson, B.J. 1989a. Response of centipedegrass (Eremochloa ophiuroides) to plant growth regulators and frequency of mowing. Weed Technol. 3:49-53.
Johnson, B.J. 1989b. Response of tall fescue (Festuca arundinacea) to plant growth regulator application dates. Weed Technol. 3:408413.

Johnson, B.J. 1988. Influence of nitrogen in the response of 'Tifway' bermudagrass (Cynodon dactylon) to flurprimidol. Weed Technol. 2:55-58.

Johnson, B.J., .R.N. Carrow, and R.E. Burns. 1988a. Centipedegrass decline and recovery as affected by fertilizer and cultural treatments. Agron. J. 80:479-486.

Johnson, B.J. and R.N. Carrow. 1988b. Frequency of fertilizer applications and centipedegrass performance. Agron. J. 80:925-929.

Kaufmann, J.E. 1985. A common sense approach to the use of PGRs. Proc. Mo. Lawn and Turf Conf. p. 69-86.

McCarty, L.B., J.M. DiPaola, W.M. Lewis, and W.B. Gilbert. 1985. Tall fescue response to plant growth retardants and fertilizer sources. Agron. J. 77:476-480.

Rogers, J.N. III, E.M. Miller, and J.W. King. 1987. Growth retardation of bermudagrass with metsulfuron methyl and sulfometuron methyl. Agron. J. 79:225-229.

SAS Institute, Inc. 1982. SAS user's guide. SAS Institute, Inc. Cary,

J. AMER. SOC. HorT. SCI. 115(3):416-422. 1990.

\title{
Evaluation of Preemergent Herbicide Phytotoxicity to Tissue, Culture-propagated 'Heritage' Red R a s p b e r r y
}

\author{
Joseph C. Neal ${ }^{1}$, Marvin P. Pritts ${ }^{2}$, and Andrew F. Senesac ${ }^{3}$ \\ Cornell University, Ithaca, NY 14853
}

Additional index words. napropamide, oryzalin, simazine, activated carbon, herbicide safening, planting-to-treatment interval, Rubus idaeus

\begin{abstract}
Five greenhouse and two Geld experiments were conducted to evaluate tissue culture-propagated (TC) raspberry (Rubus idaeus cv. Heritage) sensitivity to preemergent herbicides. Plant performance was measured by plant vigor, above-ground fresh weight, root development, and primocane number. Simazine and oryzalin caused significant injury to newly planted TC raspberry plants in greenhouse and field experiments. The severity of injury was generally linear with respect to herbicide rate, but no appreciable differences in injury were observed between the granular and spray applications. Napropamide wettable powder caused some foliar injury, but plants recovered within one growing season and growth was equal or superior to the hand-weeded controls. The granular formulation of napropamide produced similar results, but did not cause the initial foliar burn. Pre-plant dipping of roots into a slurry of activated carbon did not prevent simazine or oryzalin injury, but injury was reduced when herbicide applications were delayed. Simazine applied 4 weeks after planting was not Injurious, and oqzalin applied 2 or 4 weeks after planting caused some foliar injury, hut no reduction in plant fresh weight. Delayed treatments of napropamide increased foliar injury. Herbicide tolerance of tissue-cultured plantlets appeared to be less than that of conventionally propagated plants. Chemical names used: N,N-diethyl-2-(1-napthalenyloxy)propanamide (napropamide), 4-(dipropylamino)-3,5-dinitrobenzenesulfonamide (oryzalin), 6-chloro-N,N'diethyl-1,3,5-triazine-2,4-diamine (simazine).
\end{abstract}

Weed control is an essential component in the management of newly planted and established raspberries. Inadequate weed

Received for publication 12 June 1989. We thank Congdon and Weller Wholesale Nursery of North Collins. N.Y., for donating plant materials used in these experiments. We also thank Marcia Eaves-Sheavly, Maria Macksel, and Colleen Kearns for their excellent technical assistance. The cost of publishing this paper was defrayed in part by the payment of page charges. Under postal regulations, this paper therefore must be hereby marked advertisement solely to indicate this fact.

${ }^{1}$ Assistant Professor of Weed Science. Dept. of Floriculture and Ornamental Horticulture.

${ }^{2}$ Assistant Professor and Small Fruit Specialist, Pomology Dept.

${ }^{3}$ Extension Weed Control Specialist, Cornell Univ. Long Island Horticultural Research Laboratory, Riverhead, NY 11901. control may result in reduced survival of new plantings (Lawson and Wiseman, 1976), decreased floricane and primocane numbers (Lawson and Wiseman, 1974, 1976; Stephens and Sutherland, 1962), and thinner, less-vigorous canes (Welker and Smith, 1972). Weed competition not only affects plant growth during the growing season, but may also reduce new cane numbers the following year (Lawson and Wiseman, 1976). The effects of weeds on growth and yield have also been shown to be cumulative over time (Welker and Smith, 1972). Cultivation is used to control weedy vegetation between the rows of plants, but cannot be used within the plant rows: Hand-weeding is effective, but expensive; therefore, soil residual herbicides are generally used within the plant rows to 